publication in two volumes of Petrie's great find of papyri at Kahun and Gurob. Most of these are documents written in the cursive business hieratic of the Middle Kingdom, a script of which there had hitherto been found few, if any, examples. In his mastery of this difficult script and in his interpretation of the contents of the documents, Griffith showed that he possessed that rare gift-real genius. Many years have passed since those two volumes appeared, and there has been a great advance in our knowledge of Middle Egyptian grammar and syntax, but even so, Griffith's translations and transcriptions need comparatively few corrections.

For the next ten years or so Griffith devoted himself primarily to the study of Demotic, and by the end of that period was the foremost Demotic scholar in the world. His "Stories of the High Priests of Memphis" (1900), the "Demotic Magical Papyrus of London and Leyden", which he produced in collaboration with Sir Herbert Thompson (1907-9), and above all his "Catalogue of the Demotic Papyri in the Rylands Library" (1909) placed Demotic studies on a new footing, and gave them an interest which, in the minds of some of us at any rate, they had hitherto seemed to lack.

About the year 1907, Griffith found opportunity for winning laurels in a new field. Excavations in the Sudan and Lower Nubia were producing inscriptions in the Meroitic script hitherto undeciphered, and the finders handed them over to him to investigate. After a few years of intensive study, he could decipher the script and had advanced far towards a complete understanding of the language.

In due course Griffith turned back to Demotic and was actually engaged at the time of his death in the publication of the Demotic inscriptions occurring in the temple of Philae and in the temples of Lower Nubia, a great and most important undertaking.

In the winter season 1910-11, Griffith and his wife conducted excavations on behalf of the University of Oxford in Lower Nubia, and they continued these activities until the winter season 1913-14. In 1922 and 1923 they excavated for the Egypt Exploration Society at El-Amarna. Twice since then they have excavated in the Sudan, the site of their last campaign (1930-31) being Kawa, where they unearthed three temples, one of which had been founded by Tirhaqa. At Kawa, beside several large stelæ bearing inscriptions of great historical interest, they found a number of reliefs and statues and a quantity of other antiquities, some being of considerable artistic merit.

In 1924, in consideration of his services to Egyptology and to the University of Oxford, Griffith was given the status of professor, and, though he resigned the chair in 1932, he acted as deputy professor until the late Prof. Peet was transferred from the University of Liverpool to succeed him in October 1933. Griffith was a D.Litt. of Oxford, an honorary fellow of Queen's College, a fellow of the British Academy and also of the Society of Antiquaries, an honorary LL.D. of the University of Aberdeen and an honorary D.Phil. of the University of Leipzig. He was a correspond. ing member of the Royal Academy of Sciences at Berlin, and a foreign associate or corresponding member of many other famous learned societies in Europe.

$\mathrm{He}$ was twice married, and his second wife, who has rendered him notable assistance in his excavations in Egypt, Lower Nubia and the Sudan, and in the production of many of his publications, survives him.

Griffith was a man of wide interests. Beside a profound knowledge of Egyptology in all its branches, he was well acquainted with the archæology of his own country and of foreign countries other than Egypt. He was very fond of music and was a good naturalist and botanist. $\mathrm{He}$ was a delightful companion for a country walk, pointing out and discussing any interesting flower or plant that he observed growing in hedgerow or field; and he knew every bird by its notes. It should here be stated that his great knowledge of the birds, fish and other animals of Egypt is made manifest in many of his books and articles. A charming trait in his character was his love of children, who found in him an ideal companion. He would take them round his garden and talk to them about the birds and plants, and the creatures living in stream or pond. Small children, frightened of strangers in general, took to him immediately and, when next he appeared on the scene, welcomed him with open arms.

His was a full life and he accomplished much. He died, as all would wish to die, in full possession of all his faculties and with his mind occupied to the last in the work he loved.

Alyward M. Blackman.

\section{Dr. H. S. WAShington}

Wiтh the death of Dr. Henry Stephens Washington on January 7 at the age of sixty-six years, petrology has suffered the loss of one who, for the past forty years, has worked with distinction and has contributed greatly to the advancement of the science.

Henry Stephens Washington was born at Newark, New Jersey, on January 15, 1867, and, after due preparation, he proceeded to Yale where he obtained, in 1886, the degree of B.A. with special honours in natural sciences. After two years of post-graduate work he graduated M.A. in 1888. The next four years were spent in travelling in the West Indies, Europe, Egypt, Algeria and Asia Minor, parts of the four winters and springs being spent in Greece where he became a member of the American School of Classical Studies. In the latter capacity he assisted in and conducted excavations at Plateae, Argos and Phlius. 
Between 1891 and 1893, Washington studied petrology under Zirkel at the University of Leipzig and obtained his doctorate with a thesis on "The Volcanoes of the Kula Basin in Lydia". Afterwards he was assistant in mineralogy at Yale for a short time and continued his petrographical researches in Europe and America. From 1906 until 1912 he practised as a consulting mining geologist, and in 1912 he was appointed petrologist to the Geophysical Laboratory in Washington, a position which he still held at the time of his death.

Dr. Washington travelled extensively and the results of his geological, petrological and volcanic studies in Europe, North America, Brazil, Asia Minor and the Hawaiian Islands are incorporated in numerous publications. His devotion to the chemical side of petrology was the ruling factor in his career, and his skill as an analytical chemist and petrographer, together with an unfailing interest in volcanic processes and rocks, have contributed greatly to our present knowledge of modern lavas. At the same time his scientific activities embraced a mach wider field, and his investigations ranged from archæological subjects to problems of the earth's interior.

In 1904 he published his "Manual of the Chemical Analysis of Igneous Rocks", the fourth edition of which appeared in 1930. He was joint author with Cross, Iddings and Pirsson of "The Quantitative Classification of Igneous Rocks", published in 1903, and author of the "Chemical Analyses of Igneous Rocks" which was issued by the United States Geological Survey as a Professional Paper in 1903, and in an enlarged edition in 1917. An enormous amount of work is represented in this compilation, of which the importance, from a petrological point of view, cannot be overestimated; it must always remain an admirable memorial to its author.
It is impossible to deal adequately with Washington's scientifie publications, which form an imposing list, but among the more important may be mentioned "The Roman Co-Magmatic Region" (1906), "The Deccan Traps and other Plateau Basalts" (1922), "The Petrology of the Hawaiian Islands" (1923-1928) and "The Composition of the Earth's Crust" (1924, in collaboration with Dr. F. W. Clarke).

Dr. Washington's scientific attainments were widely recognised both in the United States and in Europe. He was a foreign member of the Geological and Mineralogical Societies of London; of the Paris Academy of Sciences; and of the Academies of Science of Norway, Turin and Modena, and of the Royal National Academy of the Lincei (Rome).

With his death, geology must mourn the passing of a great figure in the petrological world.

We regret to announce the following deaths:

Prof. J. R. Ainsworth-Davies, formerly principal of the Royal Agricultural College, Cirencester, on April 7, aged seventy-two years.

Prof. A. B. Macallum, F.R.S., formerly professor of biochemistry in the University of Toronto, lately professor of biochemistry in McGill University, on April 5, aged seventy-four years.

Sir Frederick Palmer, K.C.M.G., C.I.E., president of the Institution of Civil Engineers in 1926-27, who was a well-known bridge and harbour engineer, on April 7, aged seventy-two years.

Prof. Sydney H. Vines, F.R.S., formerly Sherardian professor of botany in the University of Oxford, president of the Linnean Society of London in 1900-4, on April 4, aged eighty-four years.

\section{News and Views}

\section{"Letters to the Editor"}

AN explanation is due to our readers for the unusually large proportion of this week's issue of NaTuRE devoted to "Letters to the Editor". In NATURE of February 10, we published an enlarged paper to provide accommodation for twenty columns of correspondence; since then, we have printed a dozen or so letters each week, which have occupied altogether a hundred columns of space. In fairness to our correspondents, it should be said that many of them have acted upon our suggestion that com. munications should be reduced in length, but still it has been difficult to ensure that prompt publication of current work which is now so widely recognised as one of the chief functions of our correspondence columns. In the circumstances, it has been decided once more to publish an extra number of pages of correspondence, in order to reduce the waiting list, and the present issue of NaTuRE therefore contains thirty-two columns under the heading "Letters to the Editor". Of the twenty-nine communications printed, about a half are from centres in Great Britain and Ireland. The remainder come from places so widespread as Copenhagen, Leningrad, Moscow and Warsaw in Europe, Boulder, Chicago, Harvard and Montreal in North America, Sendai in Japan, Cairo, and Kyancutta (South Australia). They provide further evidence, if such be needed, of the wide circulation of this journal and the keen activity with which scientific problems are being attacked in many parts of the world.

\section{Prof. G. H. Lemaître}

Prof. G. H. Lemaître, professor of mathematical methodology and the history of mathematical sciences in the University of Louvain, has been awarded the Francqui Prize of the value of 500,000 francs. The Francqui Foundation was created in 1932, and may award this annual prize to the Belgian who has made outstanding contributions to science 